\title{
UCLA
}

InterActions: UCLA Journal of Education and Information Studies

Title

Sacred Profanities: Youth Alienation, Popular Culture, and Spirituality - An Interview with Donna Gaines

Permalink

https://escholarship.org/uc/item/4tk570xh

Journal

InterActions: UCLA Journal of Education and Information Studies, 2(1)

ISSN

$1548-3320$

Author

Frymer, Benjamin

Publication Date

2006-02-09

DOI

10.5070/D421000566

Peer reviewed 


\section{Sacred Profanities: Youth Alienation, Popular Culture, and Spirituality An Interview with Donna Gaines}

\section{Introduction}

Donna Gaines is author of the highly acclaimed Teenage Wasteland, an ethnographic study of a teenage suicide pact in Bergenfield, New Jersey. Dr. Gaines is one of the world's leading authorities on youth alienation and violence. As a sociologist, journalist, and social worker, she offers a unique perspective on numerous contemporary issues shaping the lives of youth and their possibilities for transcending alienation and violence. Her most recent book, A Misfit's Manifesto: The Spiritual Journey of a Rock \& Roll Heart, is a memoir, cited by scholars as an "ethnomethodology of the self," an exploration of relationships between identity formation, popular culture, addiction, and spirituality.

Benjamin Frymer is Assistant Professor of Sociology in the Hutchins School of Liberal Studies at Sonoma State University. His writing focuses on contemporary alienation and the sociology of youth and his recent work analyzes the Columbine High School shootings as capitalist spectacle. He was one of the organizers of the Cultural Studies Matters conference at Columbia's Teachers College.

Following the Cultural Studies Matters conference in April of 2005, Benjamin Frymer had the opportunity to interview one of the conference's dynamic keynote speakers, Donna Gaines. The interview, conducted at Teachers College, allowed Dr. Gaines to further discuss some of the central issues facing America's youth, and the possibilities for young people to find meaning, hope, and change in and through popular culture.

$* * *$

BF: How do you see Teenage Wasteland today compared to when you first did the study?

DG: In 1987 I had a visceral reaction to it, an emotional response. You know this was before it was assigned to me by the Village Voice, before I got the book contract, before I wrote a dissertation or any of that. It was a gut reaction when I read about it in the newspaper. It reverberated back to my own wasted years on the streets of Rockaway Beach, Queens, New York. I had so many friends who were buried in history, silenced in history - labeled as outcasts and pushed to the side. 
Subsequently I've learned that most of us grew up in abusive or neglectful family situations. A number of us have had drug and alcohol abuse issues...body dysmorphia, you know, all of this stuff. And that's back in the middle of the 1960s, late 60s early 70s. So in 1987 Bergenfield, New Jersey I go to this town and discover that things haven't really changed that much: in fact it's worse because birth rates declined and now kids are further disadvantaged by their smaller demographics, their lack of population. The tragedy about growing up in 1987 was that youth were just not represented or even discussed except in terms of social problems. And these particular kids were kids who were not making it at school, not making it at home, not making it on the street. But they had very strong fraternital/sororital connection to each other. The peer group and the popular cultural forms they were participating in were their sources of nurturance and empowerment. Music especially, was a form of spirituality, a liberation theology of sorts.

So years go by and the book comes out as a scholarly edition, published by the University of Chicago. This is after having been an adult trade book, read by the mainstream. And by now it's being used in methods courses in sociology to teach ethnography, youth studies, class and suburban studies. So I figured okay, the story is out, maybe things will get better for kids. My purpose in writing Teenage Wasteland had been to take on the adult authority structure, which is basically my baby boom generation-the parents- but more so mental health practitioners, school officials, legislators... and just say look, "Here's a big wake-up call. This is what's happening. Kids aren't thriving. You're blaming them. You're saying they're sub-literate. You're calling them burnouts, dirtbags, and losers. What are you really giving to them? You're neglecting them. You're starving them -emotionally, physically, psychologically -- you're giving them no resources and then you're blaming them. So, what's up with that?" So that was my agenda for the first ten years.

And then after I wrote Teenage Wasteland, I wrote a second book called $A$ Misfit's Manifesto: The Spiritual Journey of a Rock and Roll Heart. That's my memoir. It's the story of my own teenage wasteland, including my discovery of sociology, all my addictions, and my relationship with popular culture. I was using the self as a sociological tool, allowing a sociological imagination to rip while going through all these life things - hoping to fuse personal experience and reflexive thinking.

These two books have been out there for a while. When my memoir came out in 2003, I put up a website and I started getting flooded with e-mail on a daily basis from kids all over the world. But also older people and young adults who were saying 'I read Teenage Wasteland when I was growing up', and, you know, 'I hated high school, and I was an addict' and 'now I'm in graduate school and I'm 
trying to figure out what to do with my life and I'm reading your memoir and its really helping me because I want to have an interesting life and do stuff that matters...but I also have to make a living and so thank you, you're the only adult I've ever trusted.' And this person is writing to me from Canada and she's maybe 28 or 29 and she's contacting me by email! And so I got letter after letter after letter. I mean it really changed my feelings about things.

Let me just back up and say that it changed my feeling that I need to start writing to youth instead of about youth, and that I need to be dealing with the healing of young people. The last couple of years I was teaching something began to shift. I was at the Graduate Faculty of New School University in New York City, teaching a graduate seminar on the sociology of popular music. Before that I was at Barnard College at Columbia. I was teaching sociology of youth or what I like to call youth studies. I was looking at popular culture, the inner and outer life of the young person, institutions, identity, the entire experience. And something shifted.

I started feeling toward the end that I really wanted to heal the psyche more than I wanted to teach theory, although I love theory and I will incorporate it wherever possible to illuminate the larger context. But I felt like there was a need to do both. I also have a social work background that compels me to heal as well as teach.

I got this letter recently from somebody and he writes 'I' $m$ sitting in the library at Bergenfield and I'm reading your book, Teenage Wasteland, and I gotta tell you I grew up in this town and I'm 20 years old and I'm tattooed and I'm in a band and punk kept me alive... and not much has really changed in the town and there's still no youth center and still the girls are cutting themselves and slashing themselves and still people are in and out of juvenile detention and still people are going for shit jobs, you know bad jobs, and everybody's thinking about going to join the military, going to Iraq... and I just want to thank you for writing this book.'

By now it's 2005. As you know the suicide pact was in 1987. So that's how many years? 18 years since the suicide pact and this punk kid is reaching out to me almost 20 years later to make sense of something so horrific and inconceivable. But then I asked myself 'where are all the kids out there that aren't going to read my book?' I just felt this immanence about the need to engage young people on a more personal level - whether at school or on the street, as a scholar and a healer.

BF: When you were starting this project initially were you intent on countering the prevalent assumptions about why kids committed suicide in particular or why 
kids were getting into trouble in general? Was there a particular ideology or discourse that you were intent on responding to?

DG: Oh definitely and it still is, the medical model, and psychology. We get locked into models and they limit what we can see. These were the predominant models of the day, in 1987, and I really wanted to bring sociology back into the narrative. I really wanted a sociological imagination to inform the discourse on youth suicide, and to incorporate social work discourse as well - to say we have to look at the person in the situation, in the historical context and ask how they are using all the available resources that they have to make meaning and to give dignity and worth to their existence. And to fight back or to be defeated...so that was my agenda.

There was something else going on in Teenage Wasteland that I wasn't as aware of as I could have been. Well there were two things. First, this was still the era before riot grrrl, before second wave feminism really hit. And I think until Angela McRobbie started writing and the Birmingham School emerged, girls were very absent. So girls are still fairly invisible in Teenage Wasteland. It was mainly focused on street culture and the boys' world. The girls were less accessible to me. There were methodological reasons why I had to stay with the boys because I started the investigation as a journalist on assignment for the Village Voice. It was hard to get girls to open up. Gender cultures were very separate. And I was looking to make a larger argument beyond Bergenfield about the decline of the industrial working class and the rise of the service economy. So the boys were overrepresented. But the bulk of my work since that time has been with young girls, about body respect, and how to access your own power and stuff. And that was a real limitation of the work. It reflected my own limitations at the time - in terms of my own historical imagination.

The second thing is, I underestimated the impact of alcohol and addiction and dismissed concepts like low self-esteem, spiritual dis-ease. In A Misfit's Manifesto I chronicle my own lifelong addiction. I was actively alcoholic at the same time that I was "Dr. Gaines," writing Teenage Wasteland. For many years I was an alcoholic/workaholic- a typical type A personality, work all day, drink all night - a two-fisted woman of letters. But I was so hell-bent on getting sociology into the narrative that I just out of hand dismissed anything that seemed individualizing, or particular to the psyche. I wanted desperately to bring sociology back into the narratives on youth, to reassert a sociological imagination.

I've subsequently engaged in research and discussion of addiction, popular culture and spirituality, including recovery and readings of Jung. Immersing myself in various theological, metaphysical and radical ecological readings as well. But I still do think that half of the load in suicide is what the structure does 
to people. The other half is what people do-action and reaction. So I saw kids fighting back through culture and through friendship groups and through just blind faith - mostly in rock $\mathrm{n}$ roll. But I didn't really look at addiction or gender culture and that is something that I'm doing now.

$B F$ : What were the social factors that you identified in trying to trace a path from the everyday lives the kids were leading to, eventually, the suicide pact?

DG: I used verstehende sociology. I took Max Weber and dropped him in my body and, you know, channeled him, raised him from the dead, which I could probably do now given my skills. I asked myself 'what would it feel like to be this person?' To really put myself in the mentality of the social actor who's experiencing life as a labeled child? But I supplemented this interpretive method by triangulating the proof. I used Weber's verstehende sociology but I also used interviews and existing data. I talked to people who knew the kids and who were labeled kids either in Bergenfield or elsewhere. And then I added to that statistics, examining more macro structural things. I think you need three layers of evidence to feel that you're somewhere near the social truth. If you get a hit on some notion three times, from the different methods of investigation you can begin to say 'wow I think I have something here' and start formulating your hypotheses. I'm trained as a positivist. I'll always think that way....and then I'll let it rip, with purpose of course.

I prepared myself for the investigation by immersing myself in the cultural text which at the time involved hardcore music, thrash metal and punk. I started listening to classic heavy metal too and I began to have an awareness of young people navigating under the radar. And I would just start watching them everywhere I went, watching how they're treated, and I'd get into fistfights at the grocery store if somebody was rude to a kid on a register cause kids can't always fight back if somebody calls them dumb or something. I'd just look at em and scream 'don't you dare talk to any American child like that or you'll deal with me.' Cause I'm an old street girl. Ya know, we're only a generation away from plastic slipcovers here and I so could take care of that person verbally abusing a kid. That was the kind of stuff that got me really angry and I just felt there was no respect for young people.

By the 1990s suicide died out as far as the statistical blip that we saw in the 80s and the hysteria about it declined too. Youth rates were always lower than adults. Actually suicide rates were even higher among college age, but "teenage suicide" was enough to get people's attention for a while.

It got quickly displaced by homicide rates and gang violence which was loaded with all sorts of race fear and gender fear, fear of males and fear of black males 
and brown males. But it was the same thing - it was the anger of a neglected and abused child, you know whether at home, or at school, in the street, or in the national agenda. And we've starved American kids on a psychic level for over a generation. And it's amazing that your generation is as loving and astute and whole as it is, you know, given what was deprived - and as you know, Ben, you're in that demographic.

And then after the homicides of the 90s, towards the end of the 90s came the kamikaze hybrid killings, which are half homicide, half suicide. Like in the shootings from Columbine to Red Lake, Minnesota where some kid who's an isolated outcast, or, maybe with a friend decides - "Hey I'm gonna go down but I'm gonna take you with me." And still nobody gets it. They won't deal with the social truth of the situation. They'll blame popular culture, they'll outlaw black trench coats and demonize goth kids but they don't grasp that so many of the kids are failing to thrive on such a profound level. I always thought that, you know, things were going to get better. But they just get different. Ya know, a little better, a little worse. The good news is young people do have a voice. You're a professor now, Ben. You have memory of history and you can change things. So much has changed, and some things haven't.

BF: I definitely want to get to the issue of the trajectory of violence, but first, in Teenage Wasteland, you used both the concepts of alienation and anomie to make sense of suicide sociologically, which are two concepts that come out of different traditions and have different implications in terms of how we should address problems such as teen suicide or depression. Would you still today make the case that a lot of these kids are in a kind of anomic condition, that there needs to be more social, community, religious guidance?

DG: I'll make that case 'til the day I die. Because the centerpiece of all my work is alienation. Because it's the most painful aspect of my own existence and the thing that informs modernity. I mean we have expunged all connection. In postmodernity we're profoundly disconnected from the earth - we think of the earth as a commodity form, disposable. We think of all the natural resources as infinitely coming off some assembly line that we can just buy and throw away. We have such a sick relationship to the earth. Alienation runs so deep to the core of the soul of our time in history... and I think it will be a generation before anyone gets it. But I feel alienation at the center of my being as a human on this planet. For example, like many people I've felt alienation as a woman. I felt it as a labeled child from a traumatic ruptured family. I felt it as somebody labeled an underachiever and a problem child in high school. I felt it as an outsider...I've done everything in my life to try to address alienation as a sociologist but also as a human being. 
As an intellectual, for many years I thought it was a really great thing to just be disconnected. That this gave me critical distance so I could sit and be separate from the social world. But Stevie Wonder says, 'you think you are in it but not of it,' well you know...we better rethink that. We're all part of this whole and it's taken me about ten years to try to figure out how to connect, how to be part of the world. And I feel much healed for it and I try to incorporate that into my work now.

It's one thing to study alienation, which Durkheim did, and it's also a good thing to consider what does give us connection, because that is what keeps us alive. We all descend from one Great Mother who - how many millions and millions of years ago was the first female somewhere in the sub-Sahara of Africa? We all come from the same source. We're all interchangeable. We're brother and sister and you don't even have to believe in God to understand that.

Durkheim was really onto something...He was really looking at what was happening, the transformations that were happening as economic forces changed and religious forces changed... and we're still reeling from it. We're still trying to figure out who we are, where we belong. We're so completely detached and what isn't helping us is the crass scientism that permeates intellectual life and expunges all the mystery out of it. I'm somewhere between Durkheim and Jung these days, trying to find something I can say to these kids that I meet, 'You are not yet whole but you can become whole and here's how you can start.' This fragmentation, this fracture that we see in the world - the postmodern world or the modern world, whatever you want to call it - is reflected in the psyche. Teenage Wasteland was a study of how alienation kills kids. A Misfit's Manifesto is a study of how it almost killed me. I'm working on a new book now, and more will be revealed.

BF: At the same time, if you go to a typical suburban high school, junior high school, you see most of the kids, in terms of appearance, pretty much conforming to what the institution wants of them, expects of them, what their family, what their suburban communities want of them. Should those kids be considered alienated in ways that the smaller groups of outsider kids are not? Which groups should we be most concerned about?

DG: I think we need to be concerned about everybody and what really changed my mind about it was, you know, I was a street kid and I started out at a community college and onward to SUNY Stonybrook and I always thought I would go back and teach at community college and teach kids like me. And I ended up at Barnard teaching Barnard/Columbia students, children that are from privilege, from elite families. I thought, wow, what problems could they have? And I learned through my students' papers that nobody gets out of childhood unscathed. In some ways material comfort might make it harder to find the 
reason for our anomic or alienated feelings. Maybe your parents aren't available; maybe they're real remote. So they farm you out to experts, to psychology, psychiatry...you know to more people who can't touch you. Parents will spend all this money to send you to the perfect private school, the perfect shrink. But they aren't there for you. So, kids experience neglect and abuse at every level.

To be fair, no parent is born with the blueprint from the Creator that says ' $\mathrm{OK}$, this is exactly what this child needs and this is how you're to administer it.' The best intending parent is just going to do the best that they can. For better or worse ninety percent of that's going to be what they got from their own parents, ten percent is what they read in the books or heard from experts. Mostly, they are just going to wing it.

So, there are many well-adjusted, happy, centered, integrated young people and I can just say that they're very lucky parents and they're very lucky kids. But I think that across categories of race and class and region and religion that you can encounter worlds of pain-depression, eating disorders, in upper class ivy league schools we see massive problems, including drinking binges. For the record, I would have thought my own drinking would have been pushed over the line from my after hours subterranean life - in the rock $\mathrm{n}$ roll world. But I really think it kicked off from having a perfectionist personality, like I gotta make an A, I gotta publish, I gotta get it to deadline...drinking and writing and writing and drinking and drinking and writing. And many, many, many alcoholics...many writers are alcoholics, creative people are, but we writers have very high rates. We labor in grueling isolation. Of course it's also genetic and tied up with early trauma and abuse but I gotta say, life in contemporary academia also doesn't help either. It can be a real killing floor for the soul.

Over time, I started to become sensitive to the ways certain environments and messages trigger these feelings of 'do or die.' And I started to get sensitive to what a kid goes through in these institutions. I wasn't brought up by white-collar workers. My parents were musicians. They had no expectations for me other than getting married and staying out of jail. But a lot of upper middle class people are under heavy pressure from, you know, kindergarten onward, their mother's tracking them, their father's tracking them...there are great expectations. And that's baby food compared to what people are doing now with their kids, it starts in pre-K. It's sick. So I feel that there's work to be done. To intervene in any arena where people are feeling an emptiness-it's coming from a very real place, from social relationships, norms, role sets...

And on top of that we still believe if you're rich and you're pretty and you're thin or smart or whatever, you're supposed to be to be loved and happy but it doesn't mean that there aren't a lot of wounds there. You know, like eating disorders, 
drinking problems, cutting, kids put on medication at the age of eleven. I think it's widespread and pervasive. But the solution of most university health services, because of their sick relationships with pharmaceutical companies is very often, 'Here sweetie, just take some anti-depressants.' Nobody's dealing with the love and care of the soul. Nobody cares. Nobody's doing it. So, that's what I'm trying to focus on now.

BF: In your latest book, A Misfit's Manifesto, one of the things at the heart of it, not only in terms of your own life but in talking about young people today, the role of music and popular culture as a way for kids to fight back, to have a space that they can feel connected to, which they don't get in many of the institutions that oppress and confine them: the family, the school, religion in many cases...Yet we hear all the time that popular culture and music are harmful to young people and that we need to steer them away from these forms of popular culture because they are corrupting; that they're much better off following the rules of institutions. How would you respond to an argument like that, which tells us to keep kids away from the influences of pop culture such as music, movies?

DG: You know I'll be generous in my view to say that both left and right of center, people have criticized the garbage aspects of popular culture, - and I'm passionately, vehemently anti-censorship - but maybe we want to do some soulsearching as a society and ask what are we really putting out there in terms of the message when we create this culture? How much TV violence do we really need? I can't even watch mainstream television anymore because I get nightmares from the themes. There's never anything positive or good presented and that's a choice, and that's pandering to the lowest common denominator of our sensibilities.

We can generate compelling culture that's uplifting and transcendent and empowering and fortifying and nourishing. But we choose not to. So I want to say that on behalf of people, who, may not understand some of the music their kids listen to and they worry that it's depressing stuff. Well, they have a point. But then there's always the other side of it. The young person might be finding a vital connection that we don't see. Like so many people, across generations, music kept me alive. People who read my memoir really identified with that. For many years I felt completely useless and worthless and hopeless except when I made the scene, when I hit the street and got involved in street culture, pop culture. I had my beginning in street gangs and the pre-Beatles doo-wop music and then into the 60s with particularly the freak culture. Frank Zappa's music was very, very radical and oppositional. It was hedonistic and very liberating for me as a woman, sexually and also for a budding intellect, in opening up my mind. It was like wow, I'm a girl and I can think! You know, that's where I got my inspiration. I never got anything at school until way, way later when I got into 
sociology. Then I had something useful. I never learned a damn thing in school except how to scam, to sabotage authority, fight or rip stuff off. Breaking and entering, ya know?

But the components of subculture, youth culture, they mirror what we get from religion. There's a saying: 'It speaks to me.' Now, when somebody loves God, really loves God, whether its Islam, or it's the God of Israel or Jesus or its Buddhist ideals of love and compassion, it resonates with who we are in our innermost being. And I'm very lucky that I do have that from popular culture and also through faith now. It took me a lifetime to really find it.

People look at kids at a Grateful Dead show years ago or a Phish concert or anything. It doesn't even matter what it is - Eminem, Alanis Morrisette, whatever it is, somebody is getting something there and what they're getting is meaning, connection, hope. How do you give hope to the hopeless?

In popular culture young people find a God of their own. And that to me, that light, that spark, that's the hope. And without hope, there's no possibility for anything. So that's why I celebrate it. I picked two chapters from Teenage Wasteland that I called: "This is Religion," I and II, which basically came from a Public Image Limited song I listened to back in those days. Music is still the kids' religion.

$B F$ : Is there a way we can encourage young people to begin to find hope in their lives? Is there a way to intervene as educators, as activists?

DG: We can do a lot. Honoring the role of culture in kids' lives is crucial. When I did this graduate seminar in the sociology of popular music at the Graduate Faculty of New School University, I had a healing agenda. I wanted to target graduate students because I think in graduate school people get the final spark of light beaten out of them if they're not really protective of themselves. And I know what kept me alive in graduate school... I had a great education. I loved my department, but what kept me alive and kept my own truth vibrant was the Ramones. Ya know and my after hours stuff hangin' around in the clubs. So as a professor, what I did, was, I had the student present a show \& tell. I also did this at Barnard. I asked students to bring in what you love, whether its music... at Barnard we did it with subculture. I called it "Youth Subcultures Day" and I got eight student volunteers to come in and talk about what they loved, everything from their sorority to goth music to sports teams. I didn't put any value judgment on it. I would not do that. I would not negate anything that gave students hope and community. I didn't want to say "Hey if you're in a sorority then you're part of the oppressor class." No, I said 'if you find value in it, then I respect it.' If you're beating up kids or you're doing something that's self-destructive then 
that's not something that we're going to celebrate, but short of that, everything is sacred. Everything is good.

At Barnard when we had our show \& tell, some students brought their mothers to class. It was fabulous. And we got to really see the inner life of the individual sitting next to us. Then, when I was at Graduate Faculty, it occurred to me that I really wanted to do healing as much as I wanted to impart theory. My thinking was, they are scholars, and they know how to read books. They don't need me for that. So I said, 'I want you to go home and think about the music that you listen to that gets you through the day and then I want you to come to class and tell us how and why that works. Then we can place it into a theoretical context.' So, I used popular culture to encourage a reflexive process. But also to get people back in touch with who they are, and then to take that truth and turn it into social theory. Instead of reading somebody else's social theory and fretting over how you can become that person, or be a clone of that scholar, I asked them to start with 'where you are or who you are.'

Look at the interior. Take C. Wright Mills' work and focus it inwardly at the self. That's what I tried to do in my memoir. A Misfit's Manifesto is a sociological memoir - it outlines how we are constructed as a self. How do we become the social actors we are? So, with my graduate students I had people interested in rave, also first wave hip hop devotees resentful of second wave hip hop, hating the gangsta stuff, thinking it was misogynistic and really exploitative and bad for the people. And then there were other people who were interested in music and political liberation in developing nations. And somebody actually had the courage to tell us that she loved Britney Spears and I thought that person was valiant. It was not a hip or popular view to confess love of mainstream pop. It was very brave to do this in a downtown New York City hipster music seminar. Mainly, I wanted to bring the heart back into academia cause I think it's not something we talk about. We're afraid that it's horribly anti-scientific. It's emotional, non-rational, you know, women's work, so it's denigrated. It's squishy and mushy. It's not Big Science. It won't help us torture rats for pharmaceutical companies or develop great weapons of mass destruction to destroy the earth. If you talk in the language of the heart, it's going to be hard to hate our neighbor.

$B F$ : In terms of the relationship kids have to the music that they listen to...there's this argument going back to the Frankfurt School, Theodor Adorno, the culture industry, that as soon as kids create some kind of authentic subculture based on a certain type of music, dress, lifestyle, drugs, what have you, that it becomes integrated into consumer society. It becomes commodified and it becomes sold to other kids and it loses its authenticity. Have you seen that happening more since you first started your study of youth? 
DG: I think its been going on...I would even take it beyond popular culture. I would even take it away from Adorno and give it to Weber because in effect, we are looking at a charismatic eruption which eventually becomes routinized. You have something come out that's authentic and new. Then, people hear it and they want it. And then it becomes mainstream, normalized, democratized, popularized. That's the way it is. And I think young people really know that. There is a feeling of loss of the sacred, the democratization of the precious, the difference between cult and mass.

BF: How do they keep that connection to music and popular culture that's theirs?

DG: I think that what's underscoring this question and this dialogue is an assumption that I don't think we can hold onto any longer - that just because something's authentic, it has value and just because something's mass culture, it doesn't. Take the case of heavy metal. People hated it! Probably the reason they sent me to Bergenfield from the Village Voice is that I was the only person who liked heavy metal. That's changed but back then, bohemia couldn't stand it. Yes, it's a mass cultural product, patriarchal, sexist... at the root, but it has some real, real meaning for people. We can't let our own class bias dirty the data.

And I think we have to be really careful, we of the knowledge producing, opinion generating classes that we don't impose our pristine politically correct orthodoxies. Adorno was a snob. I'm sure the guy never knew how to dance. This is not a guy you want to party with. I always thought he was uptight. I never met the guy but maybe I will in the next life. Ya know he himself was not so loose; how can someone like this understand anything about street life, popular culture, the body, or joy? It's a lot easier to throw shade on somebody else's parade then make one. I think that anybody who studies culture really needs a generous heart. And I probably need a more generous heart when I talk about Professor Adorno.

BF: In my own studies of the media coverage of Columbine, I focused on how youth were being demonized in new ways. Why do you think there is such sustained moral panic over young people and why is it so easy for older generations to, in a way, turn their back on youth? Why is there this gap that gets created, whether you call it the generation gap or...?

DG: Well these moral panics get projected on anybody that's other or different. Mike Males really addresses this a lot in different ways in his work. And I think that we really do project a lot of our own anxieties and insecurities on young people. 
Why do we care about suicide among young people and not the elderly? The elderly actually have the highest rates of suicide. Because young people give us some hope that things can be different. If we can't save ourselves maybe we can save them. A few years ago I ran into some surfer kids I knew in a Long Island parking lot. It happens a lot. They see the tattoos and ask, "Can you buy us beer?" I'll say no and they'll go "Well why not?" I'll answer, "Well, it's against the law." They'll bait me, "Aren't you like an anarchist?" I replied "Well no, but I'm not going to buy you beer because I don't want you to grow up like me. I wasted half my brain cells drinking. I don't want that for you." So I think it comes in part out of our fear, but also our love. I don't think we adults are the bad guys. I just think we forget. We forget. And life's increasingly demanding and parents work really hard and teachers are overloaded and everybody's too tired. I was thinking about this the other day. If we really loved our neighbor and ourselves, all our technology would be used to clean up the planet and feed it. And there'd never be anybody who would be lonely, hungry, or angry or tired or sick, but we make a different choice every day. We choose not to.

BF: How can young people best establish a sense of self and identity that will enable them to cope in such a, in many ways, difficult post 9-11 world full of anxiety, full of stress, full of competition, full of status comparisons, full of all types of forms of violence that they see out in the world? Or how can educators, activists help young people with that? Or what kinds of social institutions perhaps can be put into place to help young people really establish a sense of self that is not simply based on competing in institutions that we already have in place or on commodities?

DG: I think there's a couple of ways and one's preventative and one's ex post facto. The preventative would be if people gave some space to the care and feeding of the self. We usually think that's something people get from the family and from religion. I don't think parents can keep up with it. I think they parents do the best they can but that it's overwhelming. I think we could begin educating people about what really matters. We stopped doing that a long time ago.

What would be the great sin or crime to educate people about what it means to be a person? You know sometimes we get it in church. We get it in popular culture. We get it through literature. But why can't we build it into curricula on some level? And I think my first 'show \& tell' was a beginning glimpse of people just being able to take a deep breath and relax and be in the moment and say yes, there is joy in the world. Cause what I don't like is the doom and gloom rhetoric that comes from...from everybody. Like this terror - 'we've gotta fight the terrorists,' 'we've gotta fight the right-wing.' It's like all this doom and gloom and I think 
kids grow up hearing that and they'll have no hope. We've got to focus on the positive and find the joy in life. And there's plenty of it out there.

There's a miracle everyday, everywhere you go. Somebody's doing something kind and beautiful for another person. It's everywhere and its all the time and we just don't see it cause we don't make money from talking about that. It's not as interesting. It's also too easily dismissed as ideology. So, if we really care about the country we live in, we have to love it and we have to respect it. And that means listening to people who have views that are very different. I'm learning, trying to do that everyday.

I think it's an interesting thing, the rise of meditation and yoga, just spending quiet time in a place that transcends this, just to find your own grounding. You know like just today when I got off the subway and I had a spasm in my solar plexus cause I was trapped underground for forty minutes on the way up here and I was late. So I put my hands down and took a few breaths. We need to learn all these techniques of self-care. And it's just wisdom passed down to us. It's all there. All the knowledge in the world, everything we need is either in our heart or on a bookshelf or on the internet or in our best friend's pocket. You know, we could figure it all out and live in the Kingdom right now, but we have to have a little hope and a little faith. And so just keeping focused on the good stuff sometimes helps. 